\title{
Analysis of the Effect of Ultrasonic Welding on Microstructure
}

\author{
Tünde KOVÁCS, ${ }^{1}$ Péter PINKE ${ }^{2}$ \\ 1,2 Óbuda University, Bánki Donát Faculty of Mechanical and Safety Engineering, Department of Materials \\ Technology, Budapest, Hungary \\ ${ }^{1}$ kovacs.tunde@bgk.uni-obuda.hu
}

\begin{abstract}
Ultrasonic welding is very useful for joining thin metal sheets [1, 2]. The effect of ultrasound on microstructure is currently not well understood because the changes produced depend very much on the welding parameters and the properties of the metal being considered. Thin sheets formed by cold rolling acquire a special grain structure. During the welding process the heat produced causes recrystallization; even where heat is not applied in the joining process the recrystallization process alters the mechanical properties within the heat affected zone (HAZ). The mechanical properties of the welded samples depend on the microstructure. In this work we analyse the ultrasonic welding effect on the joint and the HAZ [3, 4].
\end{abstract}

Keywords: ultrasonic welding, heat affected zone (HAZ), recrystallization, joint.

\section{Introduction}

Welding is currently one of the most used joining technologies. We can distinguish two groups of welding technologies. In fusion welding technologies, the joint occurs by the melting of the base metals with or without filler metal. Joint established by solidification.

The Second group of welding processes is solid state welding, which produces a joint at temperatures essentially below the melting point of the base materials. In the case of this process, pressure may or may not be used.

The used high frequency ultrasound causes friction and heat. The resulting heat is lower than the melting point of the welded metal. The heat supports the establishment of a solid state welded joint. The formation of ultrasonic welded bonding can be explained by the theory of diffusion and plastic deformation.

\section{Ultrasonic Welding}

Ultrasonic Welding (USW) is a cold, solid-state welding technology, which produces a joint using high frequency friction between two or more pressed samples. When two metals are joined in this way, the process is termed Ultrasonic Metal Welding (USMW).

Ultrasonic welding involves a complex joining process between welding technologies. The joint occurs due to static pressure force and oscillatory shear force under a low level heat effect. These complex parameters (the chemical composition and the mechanical properties of the welded material, the surface roughness and the metal sheet geometry) need to be suitable for establishing a joint by ultrasonic welding $[3,4]$.

\section{Recrystallization}

Ultrasonic welding is a useful joining tech-nology for the welding of thin sheets. During this process high temperatures are created which cause recrystallization.

The recrystallization depends on the follow-ing:

- heating temperature (a thermal activated process);

- heating rate;

- heating time;

- plastic deformation;

- deformation rate;

- original grain size; 


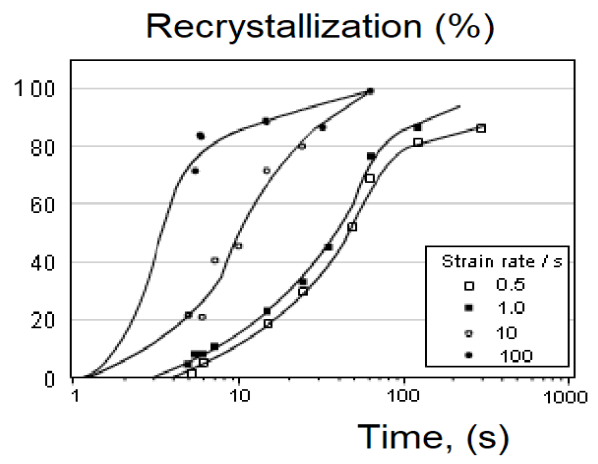

Figure 1. Relationship between recrystallization and the strain rate [5]

- secondary phases;

- solute alloy contents;

- texture before deformation.

The welding process causes a high rate of de-formation because it uses high frequency ul-trasound. The applied frequency $(20000 \mathrm{~Hz})$ causes a high rate of friction and a high rate of plastic deformation. The higher plastic defor-mation rate generates faster recrystallization (Figure 1).

It is known that recrystallization principally depends on the heating temperature and the heating time. No high temperature or long retention time was observed in our experi-ments, however, the structure was altered (particle size and grain geometry changed) $[6,7]$.

\section{Experiments}

The experiments were carried out with dif-ferent welding times; the welded pieces are showed on the Figure 2.

The welding times are summarised in Table 1. The material used was aluminum (EN 485-2:2016).

The other welding parameters used are shown in the Table 2 The visual test results of (Number 1-3) pieces were acceptable. In the case of the (Number 4-6) pieces, the defor-mation grades were more than acceptable.

The surface of sample 6 is burnt, which sug-gests overheating. The pieces which were ob-servable by visual test, were tested by tensile test and the joint cross section tested by mi-croscopy.

The microscopy test showed that the micro-structure had changed. Figure 3 shows the changes to the microstructure. The longer welding time and higher temperature caused recrystallization, grain deformation and grain coarsening in the joint and in the heat affected zone.

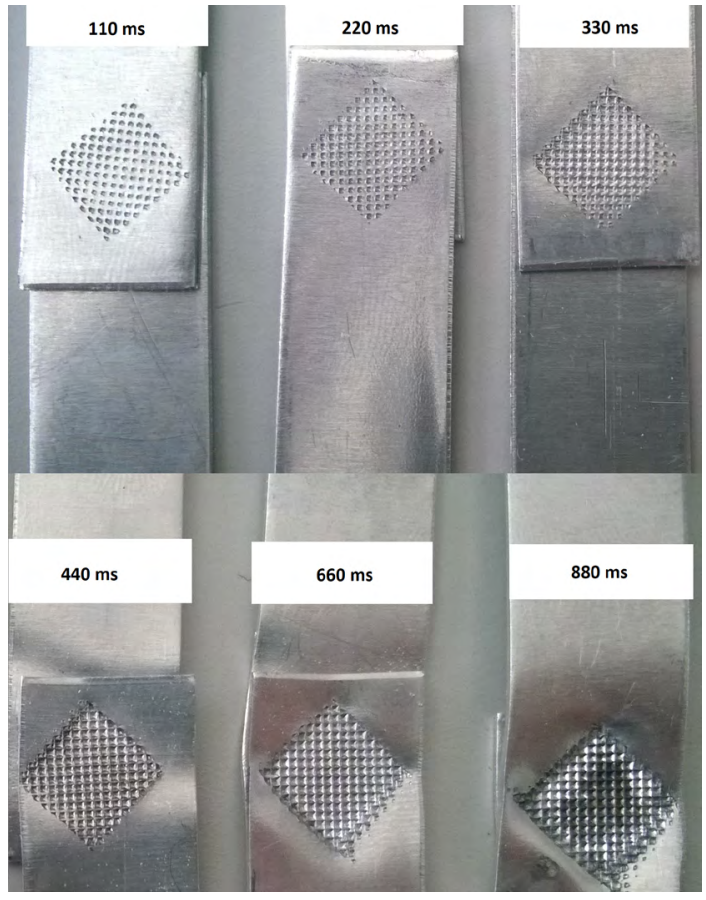

Figure 2. Different welding time effects in the case of ultrasonic welded joints

Table 1. Welding times (ms)

\begin{tabular}{|c|c|}
\hline Sample number & Welding time [ms] \\
\hline 1 & 110 \\
\hline 2 & 220 \\
\hline 3 & 330 \\
\hline 4 & 440 \\
\hline 5 & 660 \\
\hline 6 & 880 \\
\hline
\end{tabular}

Table 2. Welding parameters

\begin{tabular}{|l|l|}
\hline Trigger Force & $400 \mathrm{~N}$ \\
\hline Pressure management & $400 \mathrm{~ms}$ \\
\hline Amplitude & $86 \%$ \\
\hline Initial pressure & $0.3 \mathrm{bar}$ \\
\hline Welding pressure & $5 \mathrm{bar}$ \\
\hline
\end{tabular}

\section{Results and conclusions}

High frequency ultrasonic welding causes heat and plastic deformation. The heat and the deformation produce changes in the micro-structure of the tested materials. The defor-mation rate is unknown because of the high frequency friction. 
Recrystallization can't be explained by traditional concepts in the case of this process, because the welding time applied is very short; only $110-880$ ms.

Further analysis of the resulting microstruc-ture is necessary in order to understand the causes. It could be supposed that the resulting microstructure was created not only by the heat but also by the high rate of plastic deformation. It has been found that in the case of ultrasonic welding, cold and / or hot forming was done depending on the welding temperature.

\section{Acknowledgement}

The authors acknowledge the financial support of the Hungarian State and the European Union under the EFOP-3.6.1-16-2016-00010 project.

Furthermore, we want to tell thanks to Mihaly Szilágyi for his technical support in case of testing.
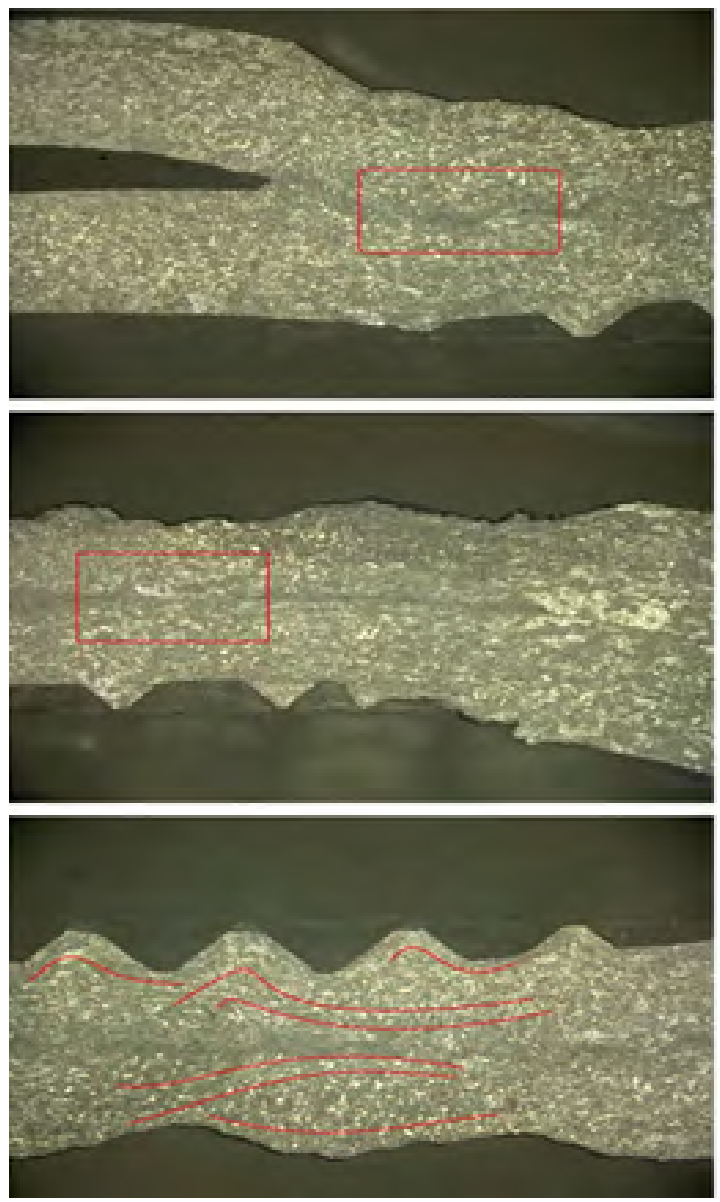

Figure 3. Ultrasonic welded joint microstructure

\section{References}

[1] Bagyinszki Gy., Bitay E.: Hegesztéstechnika II. Berendezések és mérések. EME, Kolozsvár/Cluj, 2010.

http://hdl.handle.net/10598/15438

[2] Bagyinszki Gy., Bitay E.: Hegesztéstechnika I. Eljárások és gépesítés. EME, Kolozsvár/Cluj, 2010. http://hdl.handle.net/10598/15437

[3] Kovács T.: Investigation of the ultrasound welded aluminium joint microstructure. Lecture Notes in Mechanical Engineering 49. (2018) 735-741. https://doi.org/10.1007/978-3-319-75677-6_62

[4] Szilágyi M., Kovács T.: Ultrahang hegesztés alkalmazása alumínium lemeznél. In: Proceedings of $8^{\text {th }}$ International Engineering Symposium at Bánki. Budapest, Magyarország, 2016.

http://bgk.uni-obuda.hu/iesb/2016/publication/55.pdf

[5] Callister Jr. W. D., Rethwisch D. G.: Materials science and engineering. An introduction. $8^{\text {th }}$ ed., John Wiley \& Sons Inc., USA, 2000.
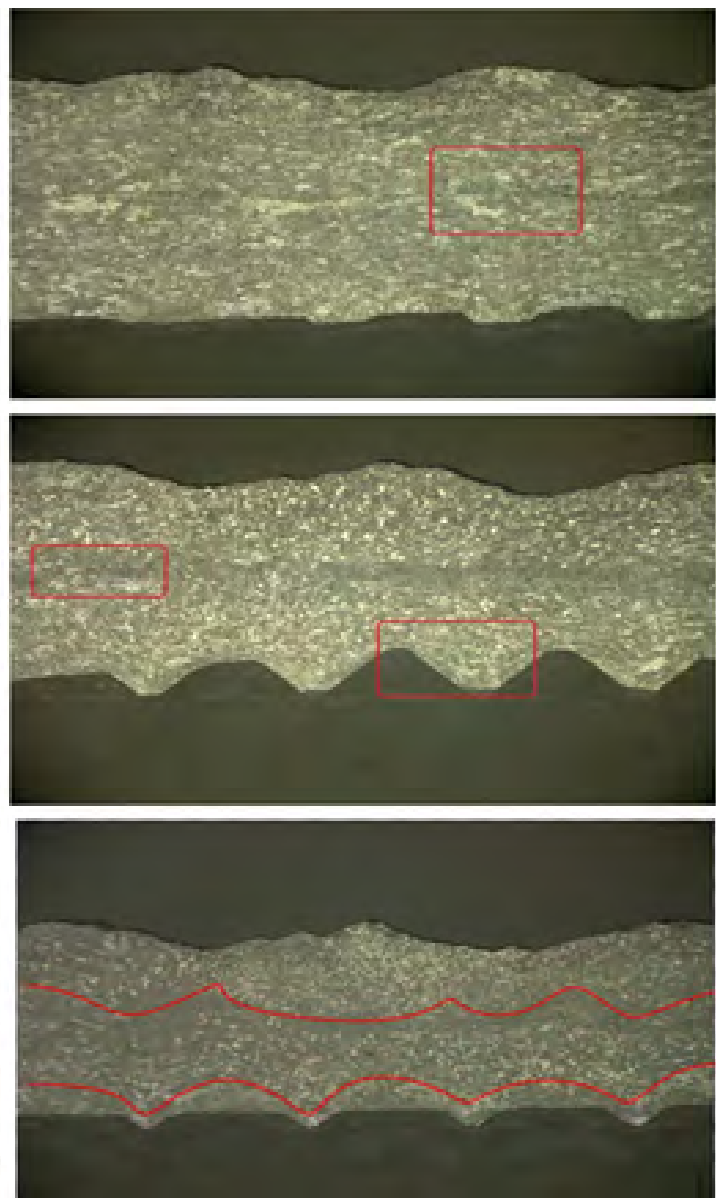
[6] Astashev V. K., Babitsky V. I.: Ultrasonic processes and machines, dynamics, control and applications. Springer-Verlag, Berlin-Heidelberg, 2007.

[7] Chen K., Zhang Y.: Mechanical analysis of ultrasonic welding considering knurl pattern of sonotrode tip. Materials\&Design, 87. (2015) 393-404.

https://doi.org/10.1016/j.matdes.2015.08.042 